\title{
Methylation and intratumoural heterogeneity of 14-3-3 $\sigma$ in oral cancer
}

\author{
UJJAL KUMAR BHAWAL $^{1,2}$, KEIICHI TSUKINOKI ${ }^{1}$, TOMONORI SASAHIRA ${ }^{2}$, FUYUKI SATO $^{3}$, \\ YUSUKE MORI $^{1}$, NORIKO MUTO ${ }^{1}$, MASARU SUGIYAMA ${ }^{4}$ and HIROKI KUNIYASU ${ }^{2}$ \\ ${ }^{1}$ Department of Oral Maxillofacial Diagnostic Science, Division of Pathology, Kanagawa Dental College, \\ Yokosuka 238-8580; ${ }^{2}$ Department of Molecular Pathology, Nara Medical University, Kashihara 634-8521; \\ ${ }^{3}$ Department of Pathology, Hirosaki University School of Medicine, Hirosaki 036-8562; \\ ${ }^{4}$ Department of Oral Health Research, School of Oral Health Science, Faculty of Dentistry, \\ Hiroshima University, Hiroshima 734-8553, Japan
}

Received March 5, 2007; Accepted June 26, 2007

\begin{abstract}
G2/M checkpoint control gene and has demonstrated that its inactivation in various cancers occurs mostly by epigenetic hypermethylation, not by genetic change. This study investigated the methylation status and expression of the 14-3-3 $\sigma$ gene in 46 oral squamous cell carcinomas by methylation-specific polymerase chain reaction, reverse transcriptase-polymerase chain reaction, Western blotting and immunohistochemistry. Exons of the p53 gene were examined for mutations by sequencing analysis and CyclinD1 by immunohistochemistry. Methylation of the 14-3-3 o gene was detected in 13\% (6/46) of the oral tumours, but not in corresponding adjacent non-malignant and normal gingival tissues. Intratumoural heterogeneity was found in the tumour tissues including three 14-3-3 omethylated samples. Methylation of 14-3-3 $\sigma$ was detected in 3 SCC with p53 mutations and 3 with wild-type p53. Our major findings are: (a) methylation of 14-3-3 gene promoter is a rare event in oral cancer; (b) it is not always associated with 14-3-3 protein levels and there is no clear relationship between its methylation and p53 mutation; (c) loss of 14-3-3 $\sigma$ expression is associated with reduced CyclinD1 gene expression.
\end{abstract}

\section{Introduction}

The 14-3-3 family of proteins consists of seven isoforms, which are highly conserved over many eukaryotic organisms

Correspondence to: Dr Ujjal K. Bhawal, Department of Oral Maxillofacial Diagnostic Science, Division of Pathology and HighTech Research Center, Kanagawa Dental College, Yokosuka 2388580 , Japan

E-mail: bhawal2002@yahoo.co.in

Key words: 14-3-3 $\sigma$, methylation, heterogeneity, oral squamous cell carcinoma, cyclinD1
$(1,2)$. Much recent interest has focused on the $\sigma$ isoform (also called HME-1 or stratifin), which is expressed in human epithelial cells (3-5). A crucial role of 14-3-3 $\sigma$ is its control of the G2 cell cycle checkpoint (6). At the G2 phase, cdc2cyclin B1 normally enters the nucleus to initiate mitosis. In response to DNA damage, 14-3-3 $\sigma$ is induced in a p53dependent manner and prevents the cdc2-cyclin B1 complex from entering the nucleus. These changes provide an opportunity for DNA repair of damage before further cell cycle progression $(6,7)$. Indeed, cells lacking 14-3-3 o function have impaired cell cycle control after DNA damage and increased genomic instability. Suppression of 14-3-3 $\sigma$ expression has been documented in transformed cell lines, including v-Ha-ras (ras)-transformed mammary cells (4), SV40-transformed human keratinocytes (8) and several types of cancer (9-12). Loss of 14-3-3 o expression is caused by DNA hypermethylation rather than gene deletion or mutation (9-13) and importantly, restoration of 14-3-3 $\sigma$ expression by the DNA demethylation agents (e.g., 5-aza-2-deoxycytidine) normalize control of the cell cycle (11).

Previous reports have shown that 14-3-3 $\sigma$ was often methylated and inactivated in human breast cancer $(12,13)$, liver cancer (9), vulval cancer (14) and oral cancer (15). Since 14-3-3 $\sigma$ is located downstream of the p53 pathway, this gene might act as a tumour suppressive factor (6). Therefore, inactivation of this gene could contribute to carcinogenesis of some cancers as shown above. On the other hand, overexpression of 14-3-3 $\sigma$ through hypomethylation was observed in pancreas cancer $(16,17)$. Moreover, it was also reported that this gene was commonly methylated in normal and malignant lymphoid cells, which nevertheless express the 14-3-3 $\sigma$ gene (18) and that the status of inactivation of this gene by hypermethylation depends upon the pathological type in lung cancer (10).

The progression of a cell through the G1 phase of the cell cycle is regulated by the sequential expression and degradation of $\mathrm{G} 1$ cyclins and the resulting activation and inhibition of cyclin-dependent kinases (CDKs). The activity of CDKs is also influenced by the concentration of specific protein molecules known as cyclin-dependent kinase inhibitors. Cyclin 
D1 is the regulatory subunit of CDK4/6, which catalyzes the phosphorylation of retinoblastoma protein $(\mathrm{pRb})$. Phosphorylated $\mathrm{pRb}$ fails to bind and inactivate $\mathrm{E} 2 \mathrm{~F}$, an $\mathrm{S}$ phase transcription factor (19). CyclinD1 overexpression plays an essential, albeit subsidiary, role in the transition between the G1 and S phase in proliferating cells. It has been reported that the accumulation of cyclinD1 in cyclinD1-overexpressing tumours (20) accelerates the cell cycle by decreasing the duration of the G1 phase (21).

14-3-3 $\sigma$ is induced by p53 in response to DNA damage (6). Cells lacking expression are defective in maintenance of G2 arrest and exhibit increased chromosomal abnormalities even in the presence of functional p53 (22). To improve our understanding of the significance of alterations in DNA methylation, we evaluated the DNA methylation status of the 14-3-3 o gene in a series of oral SCC of varying p53 status and CyclinD1 expression and examined the correlation between DNA methylation status and the protein expression levels in the same tissue samples. We showed that the loss of 14-3-3 o, via methylation-dependent transcriptional silencing, occurs as a rare event in oral cancer and it is associated with reduced CyclinD1 gene expression.

\section{Materials and methods}

Patients and samples. A total of 46 oral squamous cell carcinomas were studied. Tumours and corresponding nonmalignant epithelium were obtained at operation. We confirmed microscopically that the tumour-tissue specimens consisted mainly (>80\%) of carcinoma tissue and nonmalignant epithelium did not exhibit any tumour-cell invasion or show significant inflammatory involvement. Tissue blocks were carefully trimmed to remove non-malignant tissue before extraction of DNA, RNA and protein. In addition, a total of ten normal gingival epithelium of healthy volunteers obtained from third molar tooth extraction were included in this study. Specimens were divided into two parts: one part was snapfrozen in liquid nitrogen immediately after surgery and stored at $-80^{\circ} \mathrm{C}$ until use. The second part was formalin-fixed and paraffin-embedded. Histopathological assessment was performed on paraffin sections. The patients provided written informed consent under a protocol approved by the appropriate Institutional Review Boards.

Genomic DNA extraction and methylation-specific polymerase chain reaction. To determine DNA methylation patterns in the promoter region of the 14-3-3 $\sigma$ gene, we extracted genomic DNA using a genomic DNA purification kit (Promega, Madison, WI). Genomic DNA $(1 \mu \mathrm{g})$ was treated with sodium bisulfite as described (23) and was analyzed by methylation-specific polymerase chain reaction (MSP) (13). Primers specific for methylated DNA [5'-TGGTAGT TTTTATGAAAGGCGTC-3' (sense) and 5'-CCTCTAACC GCCCACCACG-3' (antisense)] and primers specific for unmethylated DNA [5'-ATGGTAGTTTTTATGAAAGG TGTT-3' (sense) and 5'-CCCTCTAACCACCCACCACA-3' (antisense)] yielded a 105 to 107 -bp PCR product. The PCR conditions were as follows: 1 cycle at $95^{\circ} \mathrm{C}$ for $5 \mathrm{~min} ; 31$ cycles at $95^{\circ} \mathrm{C}$ for $45 \mathrm{sec}, 56^{\circ} \mathrm{C}$ for $30 \mathrm{sec}$ and $72^{\circ} \mathrm{C}$ for $30 \mathrm{sec}$; and 1 cycle at $72^{\circ} \mathrm{C}$ for $4 \mathrm{~min}$. Two gastric cancer cell lines,
MKN74 and MKN45 were used as 14-3-3 o methylationpositive and methylation-negative, respectively (11).

Reverse transcriptase-polymerase chain reaction. Total RNA was extracted with an RNeasy mini kit (Qiagen, Hilden, Germany) from prepared frozen sections and $1 \mu \mathrm{g}$ of total RNA was converted to cDNA with a first strand cDNA kit (Amersham Pharmacia Biotech, Uppsala, Sweden). Polymerase chain reaction (PCR) was performed by using the $\sigma$-specific primers 5'-GTGTGTCCCCAGAGCCATGG-3' and 5'-ACCTTCTCCCGGTACTCACG-3' (13). The PCR conditions were as follows: 1 cycle at $95^{\circ} \mathrm{C}$ for $5 \mathrm{~min} ; 30$ cycles at $95^{\circ} \mathrm{C}$ for $45 \mathrm{sec}, 60^{\circ} \mathrm{C}$ for $45 \mathrm{sec}$ and $72^{\circ} \mathrm{C}$ for $45 \mathrm{sec}$. The PCR samples were resolved by electrophoresis in a $2 \%$ agarose gel.

Western immunoblotting. Samples containing $40 \mu \mathrm{g}$ of protein were loaded onto $12.5 \%$ polyacrylamide gels. Proteins were separated by sodium dodecyl sulfate-polyacrylamide gel electrophoresis and electrophoretically transferred to nitrocellulose membranes (BioRad, Hercules, CA). The membranes were then placed in the blocking solution at room temperature for $1 \mathrm{~h}$, washed with $0.01 \%$ Tween-PBS and incubated overnight at $4{ }^{\circ} \mathrm{C}$ with mouse monoclonal anti-14-3-3 $\sigma$ antibody (NeoMarkers, Fremont, CA). The blots were then incubated with horseradish peroxidaseconjugated secondary antibody (anti-goat IgG antibody; Medical and Biological Laboratories, Nagoya, Japan). Protein bands were visualized using the ECL Plus detection system (Amersham Biosciences, Buckinghamshire, UK).

Immunohistochemistry. Immunostaining of 14-3-3 $\sigma$ was performed on $5 \mu \mathrm{m}$-thick consecutive sections obtained from paraffin-embedded human oral tissue blocks. Sections were deparaffinized, rehydrated and then treated with $3 \%$ hydrogen peroxide in methanol for $10 \mathrm{~min}$. Antigen retrieval was done by autoclaving the slides for $10 \mathrm{~min}$ in $10 \mathrm{mM}$ citrate buffer, $\mathrm{pH}$ 6.0. After blocking with 5\% normal goat serum, the sections were incubated with anti-14-3-3 $\sigma$ antibody and antiCyclinD1 antibody (Medical and Biological Laboratories) in antibody diluent at $4^{\circ} \mathrm{C}$ overnight. Non-immune $\mathrm{IgG}$ at the same concentration as the primary antibody served as a negative control. The sections were then sequentially incubated with the Labelled Polymer, HRP for $30 \mathrm{~min}$ and with ready-to-use DAB + substrate-chromogen solution (1$3 \mathrm{~min}$ ). Then the sections were counterstained with Mayer's haematoxylin. In each specimen, the percent of positive cytoplasmic stained cells was calculated in four different fields using a x10 objective. For 14-3-3 o, we classified the cases into four categories according to their signal intensity as follows: tumour or corresponding normal tissue was scored +++ when $\geq 30 \%$ total cells present showed strong staining, or cells from multiple fields under a x10 objective lens contained areas with $\geq 30 \%$ cells staining positive. Tumour or normal tissue was considered ++ when multiple fields under a $x 10$ objective contained $\leq 30 \%$ cells staining moderately positive. Tumour or normal tissue was scored + when only a single microscopic field under a x10 objective contained $\leq 10 \%$ cells staining weakly positive on an entire slide. All tissues failing to meet at least one of the above 
A)

\begin{tabular}{|c|c|c|c|c|c|c|c|c|c|c|c|c|c|c|c|}
\hline \multicolumn{2}{|c|}{ T 2} & \multicolumn{2}{|c|}{ T 4} & \multicolumn{2}{|c|}{ T 6} & \multicolumn{2}{|c|}{ T 7} & \multicolumn{2}{|c|}{$\mathrm{H}_{2} \mathrm{O}$} & \multicolumn{2}{|c|}{$\mathbf{N}$} & \multicolumn{2}{|c|}{ MKN74 } & \multicolumn{2}{|c|}{ MKN45 } \\
\hline U & M & $\mathbf{U}$ & M & $\mathbf{U}$ & M & $\mathbf{U}$ & M & U & M & $\mathbf{U}$ & M & $\mathbf{U}$ & $\mathbf{M}$ & $\mathbf{U}$ & $\mathbf{M}$ \\
\hline & bet & 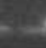 & 2 & & n- & -3 & - & & & -2 & & & 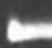 & $=$ & \\
\hline
\end{tabular}

B)

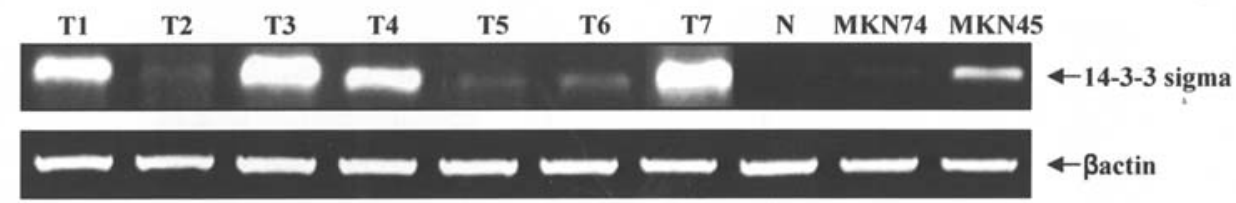

C)

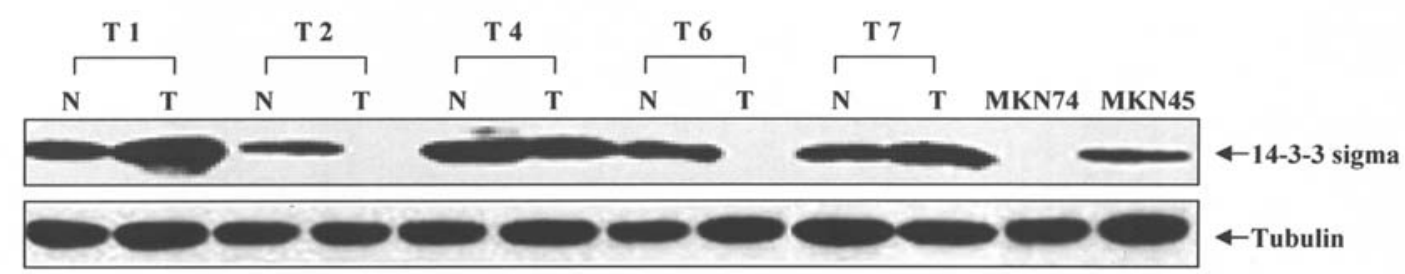

Figure 1. DNA methylation status, mRNA and protein expression levels of 14-3-3 $\sigma$ in oral carcinoma tissues. (A) Unmethylated (U), methylated (M). The methylated allele was detected only in 6 tissues. Two gastric cancer cell lines, MKN74 and MKN45 were used as 14-3-3 $\sigma$ methylation-positive and methylation-negative, respectively. (B) RT-PCR analysis of oral carcinoma tissues. Expression of 14-3-3 $\sigma$ was absent in completely methylated tissues. ß-actin mRNA was also amplified for internal control. (C) Western blot analysis in oral carcinoma tissues. Tubulin was an internal control for protein loading. N, Nonmalignant epithelium; T, Tumour.

criteria were considered negative (-). For CyclinD1, the percentage of positive cells in each case was semiquantitatively evaluated into the following two groups: i) immunoreactivity completely absent or $<5 \%$ (negative); ii) $>5 \%$ (positive). In the present study, immunostaining for CyclinD1, cases showing $>5 \%$ of positive cells were defined as 'positive' according to previous reports $(24,25)$.

PCR-SSCP and sequencing analysis of p53. Exons 4-8 of the p53 gene were examined in available 24 oral SCCs for mutations by PCR-SSCP analysis. Genomic DNA was amplified by PCR with 12 sets of primers [Primers for exon 4, 5-ATCTACAGTCCCCCTTGCCG-3 (sense), 5-GCAAC TGACCGTGCAAGTCA-3 (antisense); exon 5a, 5-TGCCC TGACTTTCAACTCTGT-3 (sense), 5-CATGTGCTGTGA CTGCTTGTA-3 (antisense); exon 5b, 5-CTGTGCAGCTG TGGGTTGATT-3 (sense), 5-GCAACCAGCCCTGTCGTC TCT-3 (antisense); exon 6, 5-GCCTCTGATTCCTCACTG AT-3 (sense), 5-CACTGACAACCACCCTTAAC-3 (antisense); exon 7, 5-TAGGTTGGCTCTGACTGTACC-3 (sense), 5-TGACCTGGAGTCTTCCAGTGT-3 (antisense); exon 8, 5-AGTGGTAATCTACTGGGACGG-3 (sense), 5-A CCTCGCTTAGTGCTCCCTG-3 (antisense)]. Each target sequence was amplified in a $20 \mu 1$ reaction volume containing 10-20 ng genomic DNA, $0.2 \mu \mathrm{M}$ dNTPs, $10 \mathrm{mM}$ Tris- $\mathrm{HCl}$ (pH 8.3), $50 \mathrm{mM} \mathrm{KCl}, 2 \mathrm{mM} \mathrm{MgCl}, 0.3 \mu \mathrm{M}$ each primer and 0.75 U AmpliTaq Gold (Perkin-Elmer, Norwalk, CT). PCR amplification consisted of 35 cycles $\left(94^{\circ} \mathrm{C}\right.$ for $30 \mathrm{sec}, 60^{\circ} \mathrm{C}$ or $55^{\circ} \mathrm{C}$ for $30 \mathrm{sec}$ and $72^{\circ} \mathrm{C}$ for $30 \mathrm{sec}$ ) after the initial activation step $\left(94^{\circ} \mathrm{C}\right.$ for $\left.5 \mathrm{~min}\right)$. PCR products were diluted 10 -fold with formamide dye solution, denatured at $85^{\circ} \mathrm{C}$ for $10 \mathrm{~min}$ and separated by electrophoresis on $15 \%$ polyacrylamide gels with $5 \%$ glycerol at a constant temperature $\left(14^{\circ} \mathrm{C}\right)$. Gels were stained and visualized with the Silver Staining II kit (Wako, Osaka, Japan). The PCR products were purified and sequenced directly with the ABI Prism Dye Terminator Cycle Sequencing kit (Applied Biosystems, Foster City, CA) and an ABI Prism 310 DNA Sequencer (Applied Biosystems).

Statistical analysis. Significant differences were analyzed by Fischer's exact test. P-values $<0.05$ were regarded as statistically significant.

\section{Results}

Methylation of 14-3-3 $\sigma$ is a rare event in oral cancer. To investigate the methylation status of the 5' CPG island of the 14-3-3 $\sigma$ gene in oral carcinoma tissues, we performed MSP of 46 oral carcinoma tissues. Representative results are shown in Fig. 1a, Table I and II. The presence of a methylated allele was detected in 6 cases (13\%). In corresponding nonmalignant epithelium, DNA methylation of the 14-3-3 o gene was not found (Fig. 1a). The methylated allele was not detected in any of the normal gingival epithelium from healthy volunteers. As shown in Table I, 14-3-3 $\sigma$ methylation status was not significantly associated with clinicopathological characteristics such as age, tumour site, tumour size and tumour cell differentiation.

Methylation of 14-3-3 o may be associated with transcriptional silencing. To assess the effect of methylation on expression of 14-3-3 $\sigma$, we performed RT-PCR of mRNA 
Table I. Methylation of 14-3-3 $\sigma$, mRNA expression level and mutation of p53 for each sample where both methylation and p53 status could be analyzed.

\begin{tabular}{|c|c|c|c|c|c|c|c|c|c|c|}
\hline \multirow[t]{2}{*}{ Sample } & \multirow{2}{*}{$\begin{array}{l}\text { Age } \\
(\mathrm{yr}) / \mathrm{Sex}\end{array}$} & \multirow{2}{*}{$\begin{array}{l}\text { Cancer } \\
\text { site }\end{array}$} & \multicolumn{3}{|c|}{ Tumour grade } & \multirow{2}{*}{$\begin{array}{c}\text { Tumour } \\
\text { differentiation }\end{array}$} & \multirow{2}{*}{$\begin{array}{l}\text { Disease } \\
\text { stage }\end{array}$} & \multirow{2}{*}{$\begin{array}{c}14-3-3 \sigma \\
\text { mRNA expression }\end{array}$} & \multirow{2}{*}{$\begin{array}{c}14-13-3 \sigma \\
\text { methylation }\end{array}$} & \multirow[t]{2}{*}{$\mathrm{p} 53$} \\
\hline & & & $\mathrm{T}$ & $\mathrm{T}$ & M & & & & & \\
\hline $\mathrm{Tl}$ & $59 / \mathrm{M}$ & Oral floor & 3 & 0 & 0 & WD & IV & ++ & $\mathrm{U}$ & $\mathrm{Mt}$ \\
\hline $\mathrm{T} 2$ & $60 / \mathrm{M}$ & Buccal mucosa & 3 & 0 & 0 & WD & III & + & $\mathrm{M}$ & Mt \\
\hline $\mathrm{T} 3$ & $42 / \mathrm{F}$ & Tongue & 3 & 1 & 0 & MD & III & ++ & $\mathrm{U}$ & $\mathrm{Wt}$ \\
\hline $\mathrm{T} 4$ & $80 / \mathrm{F}$ & Gingiva & 2 & 0 & 0 & MD & II & + & $\mathrm{M}(\mathrm{U})$ & $\mathrm{Wt}$ \\
\hline T5 & $58 / \mathrm{F}$ & Tongue & 2 & $2 \mathrm{~b}$ & 0 & MD & IV & ++ & $\mathrm{U}$ & $\mathrm{Wt}$ \\
\hline T6 & $62 / \mathrm{F}$ & Tongue & 2 & $2 \mathrm{c}$ & 0 & WD & IV & - & M & $\mathrm{Wt}$ \\
\hline $\mathrm{T} 7$ & $72 / \mathrm{F}$ & Gingiva & 3 & 0 & 0 & MD & III & + & $\mathrm{U}$ & $\mathrm{Wt}$ \\
\hline T8 & $58 / \mathrm{F}$ & Tongue & 1 & 0 & 0 & WD & I & + & $\mathrm{U}$ & $\mathrm{Wt}$ \\
\hline T9 & $79 / \mathrm{F}$ & Tongue & 1 & 0 & 0 & MD & I & + & $\mathrm{U}$ & $\mathrm{Wt}$ \\
\hline T10 & $61 / \mathrm{M}$ & Gingiva & 2 & 0 & 0 & WD & II & + & $\mathrm{U}$ & $\mathrm{Wt}$ \\
\hline T11 & $72 / \mathrm{M}$ & Tongue & 2 & 0 & 0 & WD & II & + & $\mathrm{M}(\mathrm{U})$ & Mt \\
\hline T12 & $82 / \mathrm{M}$ & Gingiva & 4 & $2 \mathrm{~b}$ & 0 & MD & IV & ++ & $\mathrm{U}$ & Mt \\
\hline T13 & 48/M & Tongue & 3 & 0 & 0 & WD & III & ++ & $\mathrm{U}$ & $\mathrm{Wt}$ \\
\hline T14 & $82 / \mathrm{M}$ & Gingiva & 4 & 3 & 0 & WD & IV & ++ & $\mathrm{U}$ & Mt \\
\hline T15 & $57 / \mathrm{M}$ & Buccal mucosa & 1 & 0 & 0 & MD & I & + & $\mathrm{U}$ & $\mathrm{Wt}$ \\
\hline T16 & 67/M & Tongue & 2 & 0 & 0 & MD & II & + & $\mathrm{U}$ & $\mathrm{Wt}$ \\
\hline T17 & $57 / \mathrm{M}$ & Gingiva & 3 & 0 & 0 & MD & III & ++ & $\mathrm{U}$ & $\mathrm{Wt}$ \\
\hline T18 & $73 / \mathrm{F}$ & Tongue & 3 & 1 & 0 & MD & III & ++ & $\mathrm{U}$ & $\mathrm{Mt}$ \\
\hline T19 & 73/M & Buccal mucosa & 3 & 0 & 0 & WD & III & ++ & $\mathrm{U}$ & $\mathrm{Wt}$ \\
\hline T20 & $70 / \mathrm{F}$ & Gingiva & 4 & 0 & 0 & WD & IV & ++ & $\mathrm{U}$ & $\mathrm{Mt}$ \\
\hline $\mathrm{T} 21$ & 59/M & Gingiva & 4 & 0 & 0 & WD & IV & ++ & $\mathrm{U}$ & Mt \\
\hline T22 & 89/M & Gingiva & 3 & 0 & 0 & WD & III & ++ & $\mathrm{U}$ & $\mathrm{Wt}$ \\
\hline $\mathrm{T} 23$ & $62 / \mathrm{F}$ & Tongue & 3 & 0 & 0 & WD & III & - & M & $\mathrm{Wt}$ \\
\hline $\mathrm{T} 24$ & $65 / \mathrm{F}$ & Palate & 4 & 0 & 0 & WD & IV & - & M & Mt \\
\hline
\end{tabular}

M, Methylated; U, Unmethylated; -, no expression; +, reduced expression; ++, normal expression; Mt, mutant; Wt, wild-type.
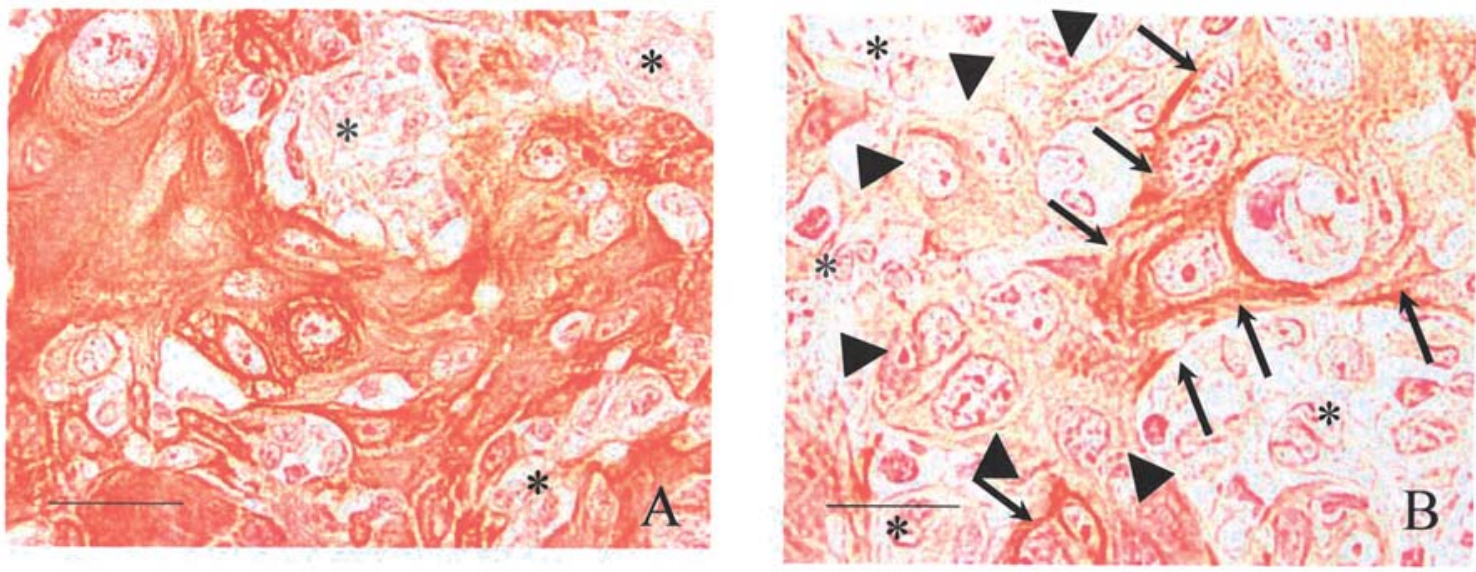

Figure 2. Intratumoural heterogeneity of 14-3-3 expression in unmethylated (A) and methylated (B) cancer. (A) Case 30: MSP (-), heterogeneity (-); (B) Case 4: MSP (+), heterogeneity (+). Arrow head: 14-3-3 (-) cancer cells, arrow: 14-3-3 (+) cancer cells, asterisk: stromal cells, bar: $50 \mu$ m. Original magnification, $\mathrm{x} 40$.

and Western blotting of protein isolated from non-malignant epithelium and tumour tissues. These studies revealed either a marked reduction or a complete absence of expression in all cases available for study in which methylation was detected by MSP (Fig. 1b). Expression of 14-3-3 $\sigma$ was observed in all 14-3-3 $\sigma$-unmethylated oral tumours (Table I). In contrast, no expression of the 14-3-3 $\sigma$ was observed in three of the six 14-3-3 $\sigma$-methylated samples. Two tumours with incomplete methylation and one specimen with complete methylation had markedly reduced expression of 14-3-3 $\sigma$. Eight out of ten (80\%) normal gingival tissues showed 14-3-3 expression although the expression of 14-3-3 $\sigma$ was higher in primary tumours when compared with nonmalignant epithelium (Fig. 1c).

Both methylated and unmethylated products were present in 2 out of 6 (33\%) 14-3-3 o-methylated tumours. Therefore, complete 14-3-3 $\sigma$ promoter methylation (only methylated product present) was detected in only 4 out of 46 primary oral tumours by methylation-specific PCR assay (Table II).

Immunohistochemistry and methylation status of 14-3-3 $\sigma$ in oral tissues. We performed immunohistochemistry for the 
Table II. Methylation of 14-3-3 $\sigma$, protein expression level, heterogeneity and CyclinD1 expression for each sample.

\begin{tabular}{|c|c|c|c|c|c|c|}
\hline Sample & $14-3-3 \sigma$ methylation & $\begin{array}{l}\text { 14-3-3 } \sigma \text { protein } \\
\text { (Western blotting) }\end{array}$ & $\begin{array}{l}14-3-3 \sigma \\
\text { staining }\end{array}$ & $\begin{array}{l}\text { Positive cell } \\
(\%)\end{array}$ & $\begin{array}{l}\text { CyclinDl } \\
\text { staining }\end{array}$ & $\begin{array}{l}\text { Positive cell } \\
\text { (\%) }\end{array}$ \\
\hline 1 & $\mathrm{U}$ & + & ++ & 16 & + & 10 \\
\hline 2 & M & - & + & 6 & - & 0 \\
\hline 3 & $\mathrm{U}$ & - & - & 0 & - & 0 \\
\hline 4 & $\mathrm{M}(\mathrm{U})$ & + & + & 7 & - & 1 \\
\hline 5 & U & + & + & 6 & - & 1 \\
\hline 6 & M & - & - & 0 & - & 0 \\
\hline 7 & $\mathrm{U}$ & - & - & 0 & - & 0 \\
\hline 8 & $\mathrm{U}$ & - & - & 0 & - & 0 \\
\hline 9 & $\mathrm{U}$ & - & - & 0 & - & 0 \\
\hline 10 & $\mathrm{U}$ & - & - & 0 & - & 0 \\
\hline 11 & $\mathrm{M}(\mathrm{U})$ & + & + & 7 & - & 1 \\
\hline 12 & $\mathrm{U}$ & - & - & 0 & - & 0 \\
\hline 13 & $\mathrm{U}$ & - & - & 0 & - & 0 \\
\hline 14 & $\mathrm{U}$ & - & - & 0 & - & 0 \\
\hline 15 & $\mathrm{U}$ & - & - & 0 & - & 0 \\
\hline 16 & $\mathrm{U}$ & - & - & 0 & - & 0 \\
\hline 17 & U & - & + & 2 & - & 0 \\
\hline 18 & $\mathrm{U}$ & - & + & 3 & - & 0 \\
\hline 19 & U & + & ++ & 12 & + & 7 \\
\hline 20 & $\mathrm{U}$ & + & +++ & 37 & + & 28 \\
\hline 21 & U & - & + & 4 & - & 0 \\
\hline 22 & $\mathrm{U}$ & - & + & 4 & - & 0 \\
\hline 23 & M & - & - & 0 & - & 0 \\
\hline 24 & M & - & - & 0 & - & 0 \\
\hline 25 & $\mathrm{U}$ & + & ++ & 21 & + & 12 \\
\hline 26 & U & + & + & 6 & - & 1 \\
\hline 27 & $\mathrm{U}$ & + & ++ & 22 & + & 11 \\
\hline 28 & $\mathrm{U}$ & + & + & 8 & - & 1 \\
\hline 29 & U & + & + & 9 & - & 2 \\
\hline 30 & $\mathrm{U}$ & + & ++ & 25 & + & 10 \\
\hline 31 & U & + & + & 8 & - & 1 \\
\hline 32 & U & + & + & 8 & - & 0 \\
\hline 33 & U & + & + & 7 & - & 2 \\
\hline 34 & $\mathrm{U}$ & + & + & 8 & - & 1 \\
\hline 35 & U & + & + & 8 & - & 1 \\
\hline 36 & U & + & + & 8 & - & 1 \\
\hline 37 & U & + & + & 8 & - & 2 \\
\hline 38 & U & + & + & 8 & - & 0 \\
\hline 39 & U & + & + & 9 & - & 1 \\
\hline 40 & U & + & ++ & 29 & + & 19 \\
\hline 41 & $\mathrm{U}$ & + & ++ & 26 & + & 10 \\
\hline 42 & $\mathrm{U}$ & + & ++ & 27 & + & 11 \\
\hline 43 & $\mathrm{U}$ & + & ++ & 28 & + & 12 \\
\hline 44 & $\mathrm{U}$ & + & ++ & 28 & + & 11 \\
\hline 45 & $\mathrm{U}$ & + & ++ & 29 & + & 18 \\
\hline 46 & U & + & +++ & 100 & + & 35 \\
\hline
\end{tabular}

M, Methylated; U, Unmethylated.

14-3-3 $\sigma$ protein on 46 oral cancer samples and showed a heterogeneous pattern of 14-3-3 $\sigma$ protein expression (32\%) with cell to cell variation (Fig. 2). Immunohistochemistry demonstrated that $70 \%$ (33 out of 46 ) of tumours were immunoreactive for 14-3-3 $\sigma$ in the cytoplasm of the cancer cells in a heterogeneous and homogeneous pattern (Table II). Positive immunoreactivity for 14-3-3 $\sigma$ was mainly expressed in the cytoplasm of differentiated squamous cells of oral cancers as well as non-malignant squamous cells. Basal cells in ten unmethylated normal gingival epithelium were scarcely positive. Tumour-to-tumour variation in the relative proportions of positive and negative cells was evident. There was a significant relationship in intratumoural distribution of 14-3-3 $\sigma$ protein between methylated and unmethylated tumours $(\mathrm{P}=0.0352)$ (Table III).

Expression of CyclinD1 is reduced in 14-3-3 o negative oral cancers. We evaluated the expression of CyclinD1, which is essential for progression through G1 phase. In normal epithelia, the expression of CyclinD1 was either not detectable or weak in the basal cell layer. Positive immunohistochemical staining for CyclinD1 was detected in the nuclei of the tumour 


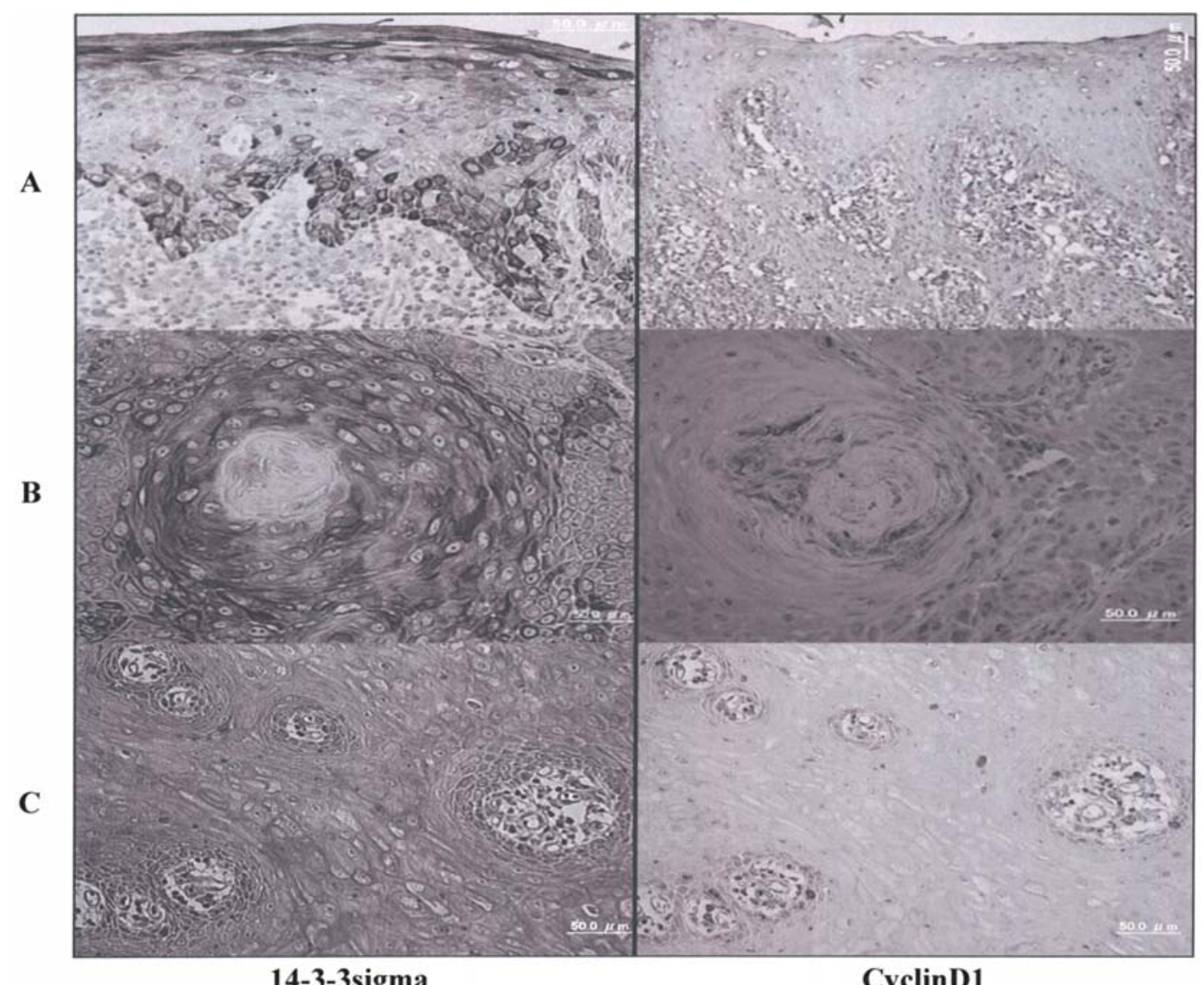

Figure 3. Immunohistochemical analysis of 14-3-3 $\sigma$ and CyclinD1 gene expression in oral cancers. (A) Normal gingiva. Basal cells were scarcely positive for 14-3-3 $\sigma$ whereas the expression of CyclinD1 was either not detectable or weak in the basal cell layer. (B) Cancer. Positive staining for 14-3-3 $\sigma$ and CyclinD1 was detected in the cytoplasm and nuclei of the tumour cells, respectively. (C) Cancer. Loss of 14-3-3 $\sigma$ expression is associated with reduced CyclinD1 gene expression. Immunohistochemical analysis was performed as described in Materials and methods. Original magnification, x40.

\section{Forward}

\begin{tabular}{cccccccc}
$c$ & $C$ & $C$ & $T$ & $G$ & $C$ & $C$ \\
\hline
\end{tabular}

Reverse

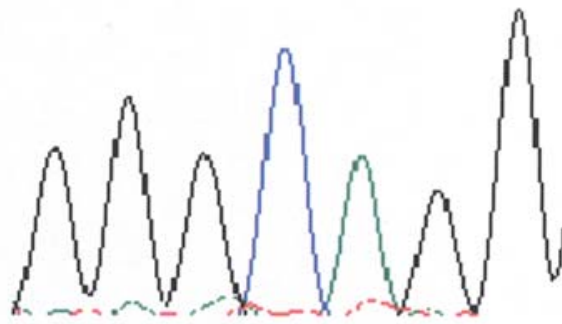

Figure 4. Mutation of exon $5(\mathrm{CCG} \rightarrow \mathrm{CTG}$ at codon 197) of p53 gene in oral cancer.
Table III. Intratumoural distribution of 14-3-3 $\sigma$ protein in methylated and unmethylated tumours.

\begin{tabular}{lccc}
\hline \multirow{2}{*}{ Methylation } & \multicolumn{3}{c}{ Expression } \\
\cline { 2 - 4 } & None/Heterogeneous & Homogeneous & $\mathrm{P}$ \\
\hline+ & 6 & 0 & \\
- & 22 & 18 & 0.0352 \\
\hline
\end{tabular}

cells (Fig. 3). CyclinD1 expression was detected in 13 out of 46 primary oral cancers (28\%) (Table II). All 14-3-3 o methylated tumours were negative for CyclinD1 protein.

Methylation of 14-3-3 o occurs irrespective of p53 status. We determined whether the frequency of 14-3-3 $\sigma$ methylation varied with p53 status. p53 mutations were present in 9 out of 24 oral SCC. Methylation of 14-3-3 $\sigma$ was detected in 3 out of 9 SCCs with p53 mutation and 3 out of 15 with wild-type p53 (Fig. 4) (Table I).

\section{Discussion}

Whether the methylation of 14-3-3 $\sigma$ exon 1 can cause loss of transcription has been a focus of discussion, since methylation of exon 1 usually does not block gene 
transcription. We observed three patterns of 14-3-3 o methylation: no methylation, complete methylation of all the $\mathrm{CpG}$ dinucleotides in the sequence, or a mixture of methylated and unmethylated alleles at varying ratios. Significant heterogeneity in methylation patterns were observed in sporadic breast cancers (26-28). For the first time, we showed that oral tumours with methylation heterogeneity due to incomplete methylation show levels of protein and mRNA transcripts that were intermediate between unmethylated tumours and tumours with complete methylation of 14-3-3 $\sigma$. However, all tumours with any degree of DNA methylation had a statistically significant reduction in 14-3-3 $\sigma$ levels when compared with unmethylated tumours. There is a small population of 14-3-3 negative cancer cells in methylationpositive tumours. This intratumoural heterogeneity provided U- and M-bands in the same tumour and positive 14-3-3 expression by Western blot and immunohistochemistry. The different portions in the same tumour showed different expression levels of 14-3-3 $\sigma$ protein. The intratumoural heterogeneity of 14-3-3 $\sigma$ protein expression in oral cancer tissues also suggests the difficulty in the prediction of histopathological diagnosis of the tumour through the estimation of 14-3-3 $\sigma$ protein levels in tumour specimens. A small population of 14-3-3 silenced cancer cells might be responsible for malignant potential of the cancer. It is important to investigate intratumoural DNA heterogeneity in order to study the mechanism of multiplicity and clinical malignancy of carcinoma.

The 14-3-3 o gene is a G2 checkpoint regulator that is aberrantly hypermethylated in several tumour types. In this study, we showed discordance between 14-3-3 o methylation as measured by MS-PCR and 14-3-3 $\sigma$ mRNA and protein expression in oral cancer. This gene displayed complete methylation and it was also partially methylated in a portion of oral tumours (Fig. 2). There was a significant relationship in intratumoural distribution of 14-3-3 $\sigma$ protein between methylated and unmethylated tumours $(\mathrm{P}=0.0352)$. The biological significance of the partial methylation observed for the 14-3-3 $\sigma$ gene in oral cancer is unclear; this result might reflect either the composite structure of this tumour or a complex pattern of methylation.

The role of methylation of 14-3-3 $\sigma$ exon 1 on gene silencing is still controversial. There is a lower incidence of 14-3-3 $\sigma$ methylation in our series (13\%) than previously reported in oral SCC based on the findings of a combination of MS-PCR, RT-PCR and immunohistochemistry by Gasco et al (15). They used 56 snap-frozen and 36 paraffin-embedded tissue sections for isolation of genomic DNA and performed MS-PCR according to Ferguson et al (13) similar to our study, with the exception that the PCR was performed for 40 rather than 35 cycles. In our study, we followed precisely the MSP technique; the same primer set, and the same sodium bisulfite reaction conditions. The MSP method we used is thought to be relevant in order to evaluate the methylation status of 14-3-3 exon 1 . The methylation pattern varied greatly, even in the same lesion, because the source of the specimen, the detection method, the number of subjects and their ages were different in each study.

The 14-3-3 protein is induced under various biological conditions, including cell cycle arrest, differentiation and apoptosis (29-32). 14-3-3 $\sigma$ has been described as a negative cell cycle regulator, because it is induced in response to DNA damage and leads to G2/M arrest (7). 14-3-3 $\sigma$ has also been described as a potent inhibitor of cell proliferation in many breast cancer cell lines. 14-3-3 $\sigma$ can also bind to and inhibit various cyclin-dependent kinases, CDK2, CDC2 and CDK4, which regulate cell cycle progression and cell proliferation and represent a novel class of CDK inhibitors (33). Negative 14-3-3 $\sigma$ cases had significantly worse overall survival rates than positive cases (34). Herein, we show for the first time that a reduction in 14-3-3 o expression in oral cancers is associated with reduced CyclinD1 expression. These data probably explain the reduction in the cell proliferation and the delay in cell cycle progression. Interestingly, all methylated tumours were negative for CyclinD1. Our results, together with previous reports, suggest that the loss of 14-3-3 o expression may be associated with tumour cell proliferation and the expression levels of 14-3-3 $\sigma$ which may be useful for predicting the malignant potential in patients with oral carcinoma.

Since p53-controlled 14-3-3 $\sigma$ expression was recognized as a key event in maintaining the G2 checkpoint, we expected that the pattern would be determined by the individual p53 status and 14-3-3 $\sigma$ in oral cancer cells. Surprisingly, no such correlation could be seen. Gasco et al found methylation of 14-3-3 $\sigma$ in 9/21 vulval SCC with p53 mutations and $11 / 15$ with wild-type p53 (14). This observation, taken together with the presence of methylated 14-3-3 $\sigma$ in cancers both mutant and wild-type for $\mathrm{p} 53$, suggests that inactivation of 14-3-3 $\sigma$ and expression of immortalizing oncoproteins from DNA tumour viruses are not mutually exclusive events.

In conclusion, we have shown that methylation of 14-3-3 gene promoter seems to be infrequent in oral cancer; 14-3-3 $\sigma$ exon 1 methylation is not directly associated with 14-3-3 gene silencing and there appears to be no clear relationship with p53 mutation. Moreover, we showed for the first time that a reduction in 14-3-3 $\sigma$ gene expression is associated with a decrease in CyclinD1 expression in oral cancers.

\section{Acknowledgements}

This study was supported in part by a Grant-in-Aid for HighTech Research Center Project and by a grant to Professor Masaru Sugiyama from the Ministry of Education, Culture, Sports, Science and Technology of Japan.

\section{References}

1. Rosenquist M, Sehnke P, Ferl RJ, Sommarin M and Larsson C: Evolution of the 14-3-3 protein family: does the large number of isoforms in multicellular organisms reflect functional specificity? J Mol Evol 51: 446-458, 2000.

2. Wang W and Shakes DC: Molecular evolution of the 14-3-3 protein family. J Mol Evol 43: 384-398, 1996.

3. Leffers H, Madsen P, Rasmussen HH, Honore B, Andersen AH, Walbum E, Vandekerckhove J and Celis JE: Molecular cloning and expression of the transformation sensitive epithelial marker stratifin: a member of a protein family that has been involved in the protein kinase C signalling pathway. J Mol Biol 231: 982-998, 1993

4. Prasad GL, Valverius EM, McDuffie E and Cooper HL: Complementary DNA cloning of a novel epithelial cell marker protein, HME1, that may be down-regulated in neoplastic mammary cells. Cell Growth Differ 3: 507-513, 1992. 
5. Vellucci VF, Germino FJ and Reiss M: Cloning of putative growth regulatory genes from primary human keratinocytes by subtractive hybridization. Gene 166: 213-220, 1995.

6. Hermeking H, Lengauer C, Polyak K, He TC, Zhang L, Thiagalingam S, Kinzler KW and Vogelstein B: 14-3-3 sigma is a p53-regulated inhibitor of G2/M progression. Mol Cell 1: 3-11, 1997.

7. Chan TA, Hermeking H, Lengauer C, Kinzler KW and Vogelstein B: 14-3-3 sigma is required to prevent mitotic catastrophe after DNA damage. Nature 401: 616-620, 1999.

8. Dellambra E, Patrone M, Sparatore B, Negri A, Ceciliani F, Bondanza S, Molina F, Cancedda FD and De Luca M: Stratifin, a keratinocyte specific 14-3-3 protein, harbors a pleckstrin homology $(\mathrm{PH})$ domain and enhances protein kinase $\mathrm{C}$ activity. J Cell Sci 108: 3569-3579, 1995.

9. Iwata N, Yamamoto H, Sasaki S, Itoh F, Suzuki H, Kikuchi T, Kaneto H, Iku S, Ozeki I, Karino Y, Satoh T, Toyota J, Satoh M, Endo $\mathrm{T}$ and Imai K: Frequent hypermethylation of $\mathrm{CpG}$ islands and loss of expression of the 14-3-3 sigma gene in human hepatocellular carcinoma. Oncogene 19: 5298-5302, 2000.

10. Osada H, Tatematsu Y, Yatabe Y, Nakagawa T, Konishi H, Harano T, Tezel E, Takada M and Takahashi T: Frequent and histological type-specific inactivation of 14-3-3 sigma in human lung cancers. Oncogene 21: 2418-2424, 2002.

11. Suzuki H, Itoh F, Toyota M, Kikuchi T, Kakiuchi H and Imai K: Inactivation of the 14-3-3 sigma gene is associated with $5 \mathrm{CpG}$ island hypermethylation in human cancers. Cancer Res 60: 4353-4357, 2000

12. Umbricht CB, Evron E, Gabrielson E, Ferguson A, Marks J and Sukumar S: Hypermethylation of 14-3-3 sigma (stratifin) is an early event in breast cancer. Oncogene 20: 3348-3353, 2001.

13. Ferguson AT, Evron E, Umbricht CB, Pandita TK, Chan TA, Hermeking H, Marks JR, Lambers AR, Futreal PA, Stampfer MR and Sukumar S: High frequency of hypermethylation at the 14-3-3 sigma locus leads to gene silencing in breast cancer. Proc Natl Acad Sci USA 97: 6049-6054, 2000.

14. Gasco M, Sullivan A, Repellin C, Brooks L, Farrell PJ, Tidy JA, Dunne B, Gusterson B, Evans DJ and Crook T: Coincident inactivation of 14-3-3 sigma and p16INK4a is an early event in vulval squamous neoplasia. Oncogene 21: 1876-1881, 2002.

15. Gasco M, Bell AK, Heath V, Sullivan A, Smith P, Hiller L, Yulug I, Numico G, Merlano M, Farrell PJ, Tavassoli M, Gusterson B and Crook T: Epigenetic inactivation of 14-3-3 sigma in oral carcinoma: association with p16 (INK4a) silencing and human papillomavirus negativity. Cancer Res 62: 2072-2076, 2002.

16. Iacobuzio-Donahue CA, Maitra A, Olsen M, Lowe AW, van Heek NT, Rosty C, Walter K, Sato N, Parker A, Ashfaq R, Jaffee E, Ryu B, Jones J, Eshleman JR, Yeo CJ, Cameron JL, Kern SE, Hruban RH, Brown PO and Goggins M: Exploration of global gene expression patterns in pancreatic adenocarcinoma using cDNA microarrays. Am J Pathol 162: 1151-1162, 2003.

17. Sato N, Maitra A, Fukushima N, van Heek NT, Matsubayashi H, Iacobuzio-Donahue CA, Rosty C and Goggins M: Frequent hypomethylation of multiple genes overexpressed in pancreatic ductal adenocarcinoma. Cancer Res 63: 4158-4166, 2003.

18. Bhatia K, Siraj AK, Hussain A, Bu R and Gutierrez MI: The tumor suppressor gene 14-3-3 sigma is commonly methylated in normal and malignant lymphoid cells. Cancer Epidemiol Biomarkers Prev 12: 165-169, 2003.
19. Hunter T and Pines J: Cyclins and cancer II: Cyclin D and CDK inhibitors come of age. Cell 79: 573-582, 1994.

20. Sherr CJ: Cancer cell cycles. Science 274: 1672-1677, 1996

21. Quelle DE, Ashmun RA, Shurtleff SA, Kato JY, Bar-Sagi D, Roussel MF and Sherr CJ: Overexpression of mouse D-type cyclins accelerates G1 phase in rodent fibroblasts. Genes Dev 7: 1559-1571, 1993.

22. Dhar S, Squire JA, Hande MP, Wellinger RJ and Pandita TK: Inactivation of influences telomere behavior and ionizing radiation-induced chromosomal instability. Mol Cell Biol 20: 7764-7772, 2000.

23. Herman JG, Graff JR, Myohanen S, Nelkin BD and Baylin SB: Methylation specific PCR: a novel PCR assay for methylation status of CpG islands. Proc Natl Acad Sci USA 93: 9821-9826, 1996.

24. Brambilla E, Gazzeri S, Moro D, Lantuejoul S, Veyrenc S and Brambilla C: Alterations of Rb pathway (Rb-p16INK4-cyclin D1) in preinvasive bronchial lesions. Clin Cancer Res 5: 243-250, 1999.

25. Kusume T, Tsuda $H$, Kawabata M, Inoue T, Umesaki N, Suzuki T and Yamamoto K: The p16-cyclin D1/CDK4-pRb pathway and clinical outcome in epithelial ovarian cancer. Clin Cancer Res 5: 4152-4157, 1999.

26. Catteau A, Harris WH, Xu CF and Solomon E: Methylation of the BRCA1 promoter region in sporadic breast and ovarian cancer: correlation with disease characteristics. Oncogene 18: 1957-1965, 1999.

27. Miyamoto K, Fukutomi T, Asada K, Wakazono K, Tsuda H, Asahara T, Sugimura T and Ushijima T: Promoter hypermethylation and post-transcriptional mechanisms for reduced BRCA1 immunoreactivity in sporadic human breast cancers. Jpn J Clin Oncol 32: 79-84, 2002.

28. Wei M, Grushko TA, Dignam J, Hagos F, Nanda R, Sveen L, Xu J, Fackenthan J, Tretiakova M, Das S and Olopade OI: BRCA1 promoter methylation in sporadic breast cancer is associated with reduced BRCA1 copy number and chromosome 17 aneusomy. Cancer Res 65: 10692-10699, 2005.

29. Fu H, Subramanian RR and Masters SC: 14-3-3 proteins: structure, function, and regulation. Annu Rev Pharmacol Toxicol 40: 617-647, 2000.

30. Muslin AJ and Xing H: 14-3-3 proteins: regulation of subcellular localization by molecular interference. Cell Signal 12: 703-709, 2000.

31. Tzivion G, Shen YH and Zhu J: 14-3-3 proteins: bringing new definitions to scaffolding. Oncogene 20: 6331-6338, 2001.

32. van Hemert MJ, Steensma HY and van Heusden GP: 14-3-3 proteins: key regulators of cell division, signalling and apoptosis. Bioessays 23: 936-946, 2001

33. Laronga $\mathrm{C}$, Yang HY, Neal $\mathrm{C}$ and Lee MH: Association of the cyclin-dependent kinases and 14-3-3 sigma negatively regulates cell cycle progression. J Biol Chem 275: 23106-23112, 2000.

34. Akahira J, Sugihashi Y, Suzuki T, Ito K, Niikura H, Moriya T, Nitta M, Okamura $\mathrm{H}$, Inoue $\mathrm{S}$, Sasano $\mathrm{H}$, Okamura $\mathrm{K}$ and Yaegashi N: Decreased expression of 14-3-3 sigma is associated with advanced disease in human epithelial ovarian cancer: its correlation with aberrant DNA methylation. Clin Cancer Res 10: 2687-2693, 2004. 